\author{
IgA ZARZECKA
}

\title{
Вечный вопрос: Какой стране принадлежит Гоголь - России или Украине?
}

\section{1. Введение}

Николай Васильевич Гоголь родился и вырос на Полтавщине в Сорочинцах ${ }^{1}$. Детские годы Гоголь провел в Васильевке, село было овеяно легендами, поверьями, историческими преданиями. Рядом с Васильевкой располагалась Диканька, которой писатель посвятил происхождение своих первых повестей.

Прапрадед Гоголя был комедиографом, писал интермедии на украинском языке. Можем догадаться, что украинский язык и украинская литература были близки молодому Гоголю2. У писателя рано пробудился интерес к литературе, еще в гимназии он был сотрудником и редактором журналов. Его привлекала Украина, песни и жизнь ее народа, хорошо знакомые ему с детства. С украинской литературной традицией растущий писатель столкнулся самым непосредственным образом: его отец Василий Афанасьевич Гоголь-Яновский был человеком образованным, одним из первых украинских писателей. Всем известна в пересказе его комедия Собакавівия. Отец Гоголя писал свои пьесы на русском языке в классицистическом духе. От отца он перенял меланхолию и веселость, дар увлекательного рассказчика, любовь к искусству, от матери - дар видеть через оболочку и горячее религиозное чувство. Отражения комедийной структуры отца замечены в творчестве автора повести Вий, так как он воспользовался творческими достижениями отца и усовершенствовал их. Итак, в семействе Гоголя говорили по-украински, но письма маминым родным писали уже на русском языке. Николай Васильевич двуязычен, но писал только по-русски и так стал известен всему миру.

Русский литературовед В.Г. Белинский в своей статье про Гоголя написал, что с Гоголем появилась новая эпоха в литературе: начался русский роман и русская повесть,

1 В. Вересаев, Гоголь в жизни: Систематический свод подлинных свидетельств современников, Москва 1990, С. 20-21.

2 И. Золотусский, Гоголь, Москва 1984, С. 8-10. 
420 | Adam Mickiewicz University Law Review

как с Пушкина началась истинно русская поэзия. Эти слова полностью указывают на то, что Гоголь был гением литературы.

\section{2. Творчество Гоголя}

Его первые произведения посвящены теме Украины: это Вечера на хуторе близ Дикань$\kappa и$ и Миргород. В Вечерах найдём много украинизмов, есть даже словарик для читателей. Таким образом, Гоголь ввёл украинский язык в русскую литературу. В это время нельзя было писать по-украински, а такой словарь был полезен для расширения знакомства с украинской речью. Вечера на хуторе близ Диканьки, в общем, посвящены теме украинской жизни. Повести, вошедшие в этот сборник, были совершенно непохожими на подражательную романтическую поэму ${ }^{4}$ Они представляли собой самобытное, примечательное явление в русской литературе. В них современности была противопоставлена поэзия народной жизни, ценность и свободолюбие украинских парубков, яркая природа Украины. Во многих повестях Гоголя, кроме идиллической обрисовки характеров, выступают черты реальной жизни. В Вечерах... видны мечты Гоголя о смелых людях. Яркая поэтическая речь его произведений отражена в русской или украинской природе, пейзаже. Писатель великолепно чувствовал все богатство русского языка, но в своих произведениях часто использовал слова украинского языка.

Вечера на хуторе близ Диканьки вызвали почти всеобщее восхищение, сделали имя Гоголя известным, успех окрылил писателя. Нарождавшаяся слава ко многому обязывала. Гоголь понял, что ограничиваться вариациями найденного никак нельзя. Жизнь писателя - это непрерывные искания, освоение новых тем, новые творческие завоевания.

Погружаясь в эти времена, отметим, что в тридцатые годы девятнадцатого столетия в русской литературе были очень популярны этнографические и фольклорные материалы, собранные на Украине, например, сборник украинских песен Михаила Максимовича. Всё началось в девятнадцатом веке после публикации Путешествия в Малороссию. Эта публикация вызвала интерес к творчеству писателей Украины, их сочинения были опубликованы в русских журналах вместе с переводом. Тема Украины надолго стала популярной в русской литературе, скорее всего большую роль сыграл романтизм, проявлявший интерес к экзотике (а Украина была для русских экзотикой).

3 Блог вчителя зарубижной литературы: Биография [online]. Блог вчителя зарубижной литературы [Доступ: 2013-07-01]. Доступны на: <http://tandev.blogspot.com/2009/03/blogpost.html>.

4 М. Храпченко, Подвиг жизни, в: Ю. Манн, Гоголь и мировая литература, Москва 1988, C. 5 . 
Начало профессиональной деятельности Гоголя проходило под знаком романтизма. Специфика романтизма Гоголя, основана на украинском барокко и приеме древнерусской литературы.

После приезда в Петербург молодой писатель с удовольствием заметил, что Украина в моде. Читателям было интересно прочитать про украинский фольклор, они с нетерпением ожидали новых публикаций на эту тему. Гоголь знал украинскую жизнь в деталях и подробностях и в это время он написал свои знаменитые Вечера. Он даже получил отзыв от самого Пушкина, который написал на них рецензию:

Сейчас прочёл Вечера близ Диканьки. Они изумили меня. Вот настоящая весёлость, искренняя, непринуждённая, без жеманства, без чопорности. А местами какая поэзия! Всё это так необыкновенно в нашей нынешней литературе, что я доселе не образумился $(\ldots)^{5}$.

Сближение с Пушкиным оказало большое влияние на развитие писателя.

Сборник повестей Миргород основан на украинском фольклоре и состоит из четырех различных по объему и тематике повестей: Старосветские помещики, Тарас Бульба, Вий и Повести о том, как поссорился Иван Иванович с Иваном Никифоровичем. Миргород ознаменовал шаг Гоголя в сторону реализма закрепив и углубив ту тенденцию, которая наметилась еще в Вечерах... Гоголь обращается к истории простого народа, к Украине, старается показать общую картину борьбы за независимость запорожского казачества. Писатель сумел показать вольную независимую натуру казаков. Считается, что этот сборник - продолжение Вечеров на хуторе близ Диканьки.

Первый прозаический цикл Николая Васильевича показывает интересную тенденцию в его творчестве - стремление войти в большую русскую литературу и культуру. Этого можно было добиться одним путём - публикациями на русском языке. Как утверждают биографы Гоголя, если в Вечерах Гоголь еще нередко пользовался оборотами и конструкциями украинской речи, то уже после Миргорода он почти полностью отказался от этого, обращаясь к нормам русского литературного языка.

Писатель был на распутии, и это было замечено его друзьями. Даже приятельница Гоголя Александра Смирнова-Россет в одном из писем затронула вопрос принадлежности писателя. Он так ответил на этот вопрос:

Скажу вам одно слово насчет того, какая у меня душа, хохлацкая или русская, потому что это, как я вижу из письма вашего, служило одно время предметом ваших рассуждений и споров с другими. На это вам скажу, что сам не знаю, какая у меня душа, хохлацкая или русская. Знаю только то, что никак бы не

5 М. Храпченко, Подвиг..., С. 4. 
422 | Adam Mickiewicz University Law Review

дал преимущества ни малороссиянину перед русским, ни русскому перед малороссиянином. Обе природы слишком щедро одарены Богом, и как нарочно каждая из них порознь заключает в себе то, чего нет в другой - явный знак, что они должны пополнить одна другую. Для этого самые истории их прошедшего быта даны им непохожие одна на другую, дабы порознь воспитались различные силы их характеров, чтобы потом, слившись воедино, составить собою нечто совершеннейшее в человечестве ${ }^{6}$.

Мы выдвигаем следующую гипотезу: может быть, малой Родиной для Гоголя была Украина, а великой - Россия. Будучи в Петербурге, Гоголь никак не мог забыть про свою малую родину. Он был участником собрания малорусов, они ели вареники и голубцы, пели песни. В этнографическом и бытовом смысле писатель вёл себя как малоpocc. У него был специфичный украинский юмор, смех Гоголя универсален - он охватывает все проявления человеческой души, начиная от низких и кончая высокими ${ }^{7}$ Гоголь осознавал себя представителем русской литературы.

Надо вспомнить в этом месте про любовь Гоголя к украинским песням. Он их собирал и, в конце концов, написал о них статью. Статья об украинских песнях - гимн в их честь. Для Николая Васильевича в них отражено музыкальное разнообразие фольклора Украины, уникальное стихосложение влияет на мелодичность песен. В песнях можно найти драматичное звучание минувшей старины.

Мы обратили внимание на малую родину, теперь расскажем о великой. Интересно, как Гоголь назвал Россию в своём романе Мертвые души: он не написал просто Россия, только использовал определение Русь. Общеизвестно, что Русь связана с Киевом. А Киев принадлежит Украине. Николай Васильевич написал статью под названием: Взгляд на составление Малороссии, в которой подчеркнул важную роль Киева:

Киев - древняя матерь городов русских - сильно разрушенный страшными обладателями табунов, долго оставался беден и едва ли мог сравниться со многими, даже не слишком значительными городами северной России ${ }^{8}$.

Тем самым писатель обратил внимание на общее прошлое и христианские корни. Он пишет:

6 О. Кудрин, Песня на два голоса. О национальной идентичности Николая Гоголя-Яновского [online]. Архив материалов [Доступ: 2013-07-01]. Доступны на: <http://aticel.ucoz. ua/news/e_mne/2012-10-28-2>.

7 И. Золотусский, Гоголь, С. 4.

8 Взгляд на составление малороссии [online]. ФЭБ [Доступ: 2013-07-01]. Доступны на: $<$ http://feb-web.ru/feb/gogol/texts/ps0/ps8/ps8-040-.htm>. 
Да и вообще Россия все мне становится ближе и ближе. Кроме свойства родины, есть в ней что-то еще выше родины, точно как бы это та земля, откуда ближе к родине небесной9.

Таков путь Гоголя: от малой родины к родине великой и от нее к родине небесной. Николай Васильевич считал Россию храмом, монастырём и говорил: Монастырь ваш Россия. Такой небесной станцией для писателя стала Россия, понимаемая как общая Русь.

\section{Общерусская культура}

Местонахождение раннего творчества Гоголя - на границы русской и украинской культур, и об исключительной принадлежности к русской культуре нельзя говорить. Надо обратить внимание на культурный фон его эпохи. Можно сделать вывод об отсутствии единства в понимании общерусской культуры и об отсутствии ее интегральной концепции.

Хронологические рамки существования общерусской культуры определяются со второй половины XVII века до середины XIX века, именно в это время в 1831 г., дебютировал Николай Васильевич. Выделение общерусской культуры оправдано в истории общественного сознания, политической идеологии, литературного языка, изобразительного искусства, музыки, архитектуры, а также в истории художественной литературы, наиболее ярким примером чего может служить творчество Гоголя.

С этой точки зрения можно рассматривать соответствия культуры общерусской - великорусской в Великороссии и общерусской - украинской в Украине. Распад культурной диглоссии связывается с процессом превращения украинской культуры в самодостаточное явление со второй половины XIX века и с соединением общерусской культуры с великорусской в единую культурную систему. Этот термин рассматривается только на культурно-идеологическом уровне, но не в этногенезе: носители общерусской культуры и общерусского сознания не перестают быть представителями своих народов.

Диглоссия - особый вариант билингвизма, при котором на определённой территории или в обществе сосуществуют два языка или две формы одного языка, применяемые их носителями в различных функциональных сферах. Для диглоссии характерна ситуация несбалансированного двуязычия, когда один из языков или вариантов выступает в качестве высокого, а другой - низкого. При этом возможны ситуации, когда низкий язык является родным разговорным языком для всего населения территории или его части, а высокий язык - родственным по отношению к родному языку либо

9 Блог вчителя зарубижной литературы: Биография [online]. Блог вчителя зарубижной литературы. [Доступ: 2013-07-01]. Доступны на: <http://tandev.blogspot.com/2009/03/blogpost.html>. 
424 | Adam Mickiewicz University Law Review

неродственным надэтническим языком территорий с разнообразным этническим составом населения ${ }^{10}$.

В первой половине XIX века становление высокой украинской культуры еще только начиналось, поэтому творчество Гоголя могло существовать только в рамках общерусской культуры. Однако эта разновидность общерусской культуры определяется как общерусская культура на малорусской, то есть украинской основе. Уточняется, что к этой культуре принадлежат не только украинские повести Гоголя, но и петербургские повести, Ревизор и Мертвые души. Признаком принадлежности к ней является не украинское происхождение Гоголя и не украинская тематика его ранних произведений, а генетическая связь гоголевского творчества с украинской культурой XVII -XIX веков.

Политико-идеологические взгляды Гоголя мы рассматриваем как утопическую попытку национального синтеза в контексте общерусскости.

В конце статьи делается вывод о культурно-национальной принадлежности творчества Гоголя: в категориях XIX века оно причисляется к общерусской культуре на украинской основе, в современных культурных категориях оно рассматривается и как достояние русской культуры и литературы, и как достояние украинской культуры и литературы одновременно ${ }^{11}$.

\section{3. Заключение}

Подводя итоги, надо подчеркнуть, что литература - это такое специфическое явление, которому нельзя придавать никаких, даже народных пределов. Интерес к произведениям и личности Гоголя в последнее десятилетие вызван как загадочностью его творчества, так и пограничной, русско-украинской сущностью его художественного мышления.

Вечера на хуторе близ Диканьки созданы на богатом украинском этнографическом материале, в повести проявилось характерное для Гоголя смешение романтических и реалистических красок. Указанный сборник отразил романтическую мечту писателя о красоте, о простой, естественной и свободной жизни никем не угнетаемого, счастливого, преодолевающего любые препятствия человека. В следующем сборнике повестей Миргород, центр тяжести художественного изображения был перенесен на полную мелких забот и неприятностей повседневную жизнь обывателей. Романтические темы и конфликты были переведены в реалистическую плоскость, что повлекло за собой перестройку всех уровней поэтики.

В соответствии с тогдашним пониманием общерусской культуры, творчество Гоголя является общим благом. Вслед за исследователями литературы мы можем уточ-

10 Диглоссия [online]. Словари и энциклопедии на Академике [Доступ: 2013-07-01]. Доступны на: < http://dic.academic.ru/dic.nsf/ruwiki/490654>.

11 Творчество Гоголя как явление [online]. Васильевич Гоголь Николай [Доступ: 2013-0701]. Доступны на: <http://www.nikolaygogol.org.ru/>. 
нить термин общерусской культуры: он появился на малорусской основе. Мы хотим ответить на вопрос, указанный в теме: какой стране принадлежит Гоголь? Ответ один: никакой. Гоголь как писатель считается представителем общерусской литературы, ни украинской и ни русской. У него были украинские корни, выше упомянутая малорусская основа, но творчества писателя не возможно отнести к одному конкретному типу к одной национальной литературной традиции. Литература должна объединять, а не делить.

Статью хотим окончить афоризмом Гоголя: В литературном мире нет смерти, и мертвець так же вмешиваются в дела наши и действуют вместе с нами, как живые $e^{12}$. Как говорит французский философ Луи-Габриэль-Амбруаз Бональд: литература есть выражение общества, так же как слово есть выражение человека ${ }^{13}$. Творчество Гоголя оказало большое влияние на многих выдающихся русских писателей, имело огромное значение для развития русской литературы. Николай Васильевич создавал великолепную литературу. Творчество Гоголя является воплощением каждого человека.

\section{Биографическая аннотация:}

Iga Zarzecka - студентка Университета им. Адама Мицкевича, факультета польской филологии. Научные интересы: русская и украинская литература и культура.

\section{SUMMARY}

\section{Internal question: To which country Gogol belongs to - Russia or Ukraine?}

The aim of the study is to evaluate the status of an artist's cultural heritage in the national context on the example of Nikolaj Gogol. The author makes an attempt to answer whether Gogol's work belongs to Russia or Ukraine by presenting the status of the particular oeuvres of the artist.

KEYwords: Nikolaj Gogol, cultural heritage, cultural property

12 Цитата Николая Васильевича Гоголя [online]. Великие слова [Доступ: 2013-07-01]. Доступны на: <http://greatwords.ru/quote/11535/>.

13 Афоризмы и цитаты о литературе [online]. Цитаты [Доступ: 2013-07-01]. Доступны на: $<$ http://citaty.su/aforizmy-i-citaty-o-literature $>$. 
